\title{
Human Capital Costs in the Context of Coronavirus Crisis
}

\author{
Slavka Šagátová ${ }^{1, *}$ \\ ${ }^{1}$ FPM EU in Bratislava, Department of Business Economy, Dolnozemská cesta,1 85235 Bratislava, \\ Slovakia
}

\begin{abstract}
Human capital is an important motor of business performance. In this context, the costs of human capital that the company spends in its efforts to ensure the development and achieve growth in its performance play an important role. However, in times of crisis and decline of production, labor costs that cannot be eliminated become unproductive. The sensitive area is especially area of the wage costs that the company has to pay to employees and thus they represent not only the loss for the company but also the cash outflow. The article maps the influence of this factor on individual branches of the Slovak economy. Using data on the volume of wages paid and estimates of scenarios for the possible development of the coronavirus crisis, it identifies the most vulnerable sectors in terms of unproductive labor costs.
\end{abstract}

\section{Introduction}

Human capital is an important part of the business economy, and investing in this area of production factors ensures the prosperity of the company. However, with the reduction of corporate production due to the coronavirus crisis, the costs of human capital are becoming an item that reduces corporate profits. A significantly negative feature of these costs is the transformation of a large part of labor costs directly into losses, which further exacerbates the possibility of remediation of damages from the decline in production by enterprises. The high share of labor costs thus becomes a risk factor for the survival of companies. The inability of companies to pay wages can lead to the loss of employees in individual companies. In a broader context, this situation can lead to rising unemployment and, in this context, to further negative effects on the costs economy as a whole.

\section{The essence of human capital}

The OECD defines human capital as the knowledge, skills, abilities and other characteristics of an individual that are relevant to economic activity. [1] From the company's point of view, therefore, human capital is an essential input into production factors in the form of human resources. Exploring this issue is important as good human

\footnotetext{
* Corresponding author: slavka.sagatova@euba.sk
} 
resource management practices can contribute to stabilizing and creating good conditions for maintaining a workforce. [2,3] By inducing interactions to gather and exchange knowledge, human capital contributes to the growth of innovation. [4, 5] To use human resource management as a tool for performance management, it is important to know the basic principles that allow employees to be involved in these management processes. [6]

The human capital costs can be considered as certain investments that are made by companies to improve human activity. It is especially important to match investments into human capital with the needs of the company and the ability to use human potential. [7] It is inefficient if the company invests in developoment of employees and then the acquired skills cannot be used by them. On the other hand, it is very important for the company to invest in necessary education, skills and abilities of employees, which are inevitable for the efficient production activity of the company. The company can make these investments in human capital by obtaining it from the external environment (funds spent on acquiring quality employees) or by investing in the internal environment (providing training to employees, incentive programs for employees - wages, benefits). However, these investments can also be seen in the broader context of building an employer brand, which will enable the acquisition of qualified employees for the company. [8]

The immediate picture of investing in human capital in a company are the personnel costs. The advantage of this parameter is the possibility of its unambiguous quantification. Personnel costs represent the evaluation of the labor force as a basic production factor and other costs related to ensuring its use in the transformation process. For effective cost management, it is first and foremost necessary to know them. In the case of personnel costs, we can talk about direct wage costs and other costs related to production workers, other "overhead" employees as well as personnel department operating costs of the. there are mutual interactions in all these groups when implementing the business activities. It is necessary to be aware of the importance labor costs, which can be an important motivating element in increasing the performance of business.

Although the current performance studies point to the growing importance of social processes and the focus on manager-employee interaction [9], the importance of wages as a motivating factor cannot be overlooked. There are also studies confirming the impact of salary on employee satisfaction and loyalty. [10] However, the degree of sensitivity to remuneration can also be perceived in a broader context, as an indicator of the employee's response to various stimuli from the company, for example in the form of training. [11] It should be noted, however, that the different effect in this area will be influenced by the very perception of wages by the individual in the context of other employment benefits. [12] As a starting point can be considered a combination of internal motivation and managerially well-managed management (job identification, remuneration strategies, etc.). [13]

In case of a loss of revenues during crisis, it is possible to reduce or completely eliminate the expenditure of certain personnel costs, such as costs associated with recruiting or employees training. However, such a solution is not possible at all types of these costs. The main problem may be the wage costs paid to employees, which become unused costs if the company does not produce. As it is difficult for a company to keep the work of employees in stock and consume it later, unused (non - productive) labor costs are a serious problem. It is only possible in the short term not to transmit performance shocks to employees, in line with the notion that firms isolate workers from idiosyncratic shocks consistent with the notion that firms insulate workers from idiosyncratic shocks [14] is possible only for a short time period. 


\section{Methodology}

Nowadays in the context of coronavirus crisis and its impacts on human capital, the currently emerging problem appears to be the labor costs that companies are forced to pay to the employees regardless of the decrease in their profits and a drop in revenues. The aim of the article is, therefore, to point out the possible effects of labor costs in the event of a decline in production, focusing on individual sectors of the Slovak economy.

As a data source, we used the databases of the Statistical Office SR [15] and the government statement on the termination of the economy. Data on the number of employees and the average salary was examined in more detail. The sectoral structure of average salaries calculated from the data for 2019 was used to assess the situation in individual sectors, provided that this structure has not changed in the following period.

The development of production during the crisis willbe estimated based on data publicly presented by government officials and resulting from measures to close selected companies. According to the regulation valid from 16.3.2020 [16], all retail establishments and services were closed except groceries, drugstores, pharmacies, medical device stores, newspapers, post offices, banks, insurance companies, petrol stations, pet shops, and veterinary clinics. Restaurants could have stayed open, but people were not allowed to gather there, but they could have taken takeaway food. International airports were closed, as well as the international train and bus transportation was stopped (except for cargo transports). School facilities, social, cultural facilities, ski resorts, and wellness centers, and aquaparks were also closed. Part of these measures was abolished on 6.5.2020. [17]

\section{Results and Discussions}

The crisis caused by the coronavirus pandemic has dampened the economy. The overall decrease in production is said to be by $30 \%$ (according to the statement of Prime Minister in March 2020) [18]. The amount of labor costs is an important factor playing an important role in terms of the survival of vulnerable sectors, which burden their financial management and are a significant component of cash flow outflow.

In the context of revenues drop, the number of wages that were paid even though they did not contribute to ensuring the company's performance can be considered. Therefore it is possible to talk about unused labor costs. Unused labor costs depend on two parameters: the volume of wages paid and the extent of the company's production downtime. The largest volume of unused labor costs can, therefore, be observed, especially in the sectors with the most massive volume of wages paid. (In order to get a picture of the total amount of costs related to employees' wages, it is necessary to add wage levies to the value of wages paid.)

According to the average data from 2019 (Statistical Office of the Slovak Republic, 2020 ), the most wages paid were in the industry sector, which employed $27 \%$ of all employees, and $27 \%$ of all wages were paid in it. In second place are the branches of Public Administration, Defense and Compulsory Social Security, which employed $11 \%$ of all employees and paid $13 \%$ of all wages. The third is the education sector, employing $11 \%$ of all employees out of all, and $10 \%$ of all wages were paid. In fourth place is the wholesale and retail sector, which employed $10 \%$ of employees, to whom $10 \%$ of wages were paid. In fifth place is the sector of healthcare and social assistance sector with $8 \%$ of employed persons and $8 \%$ of wages paid. 


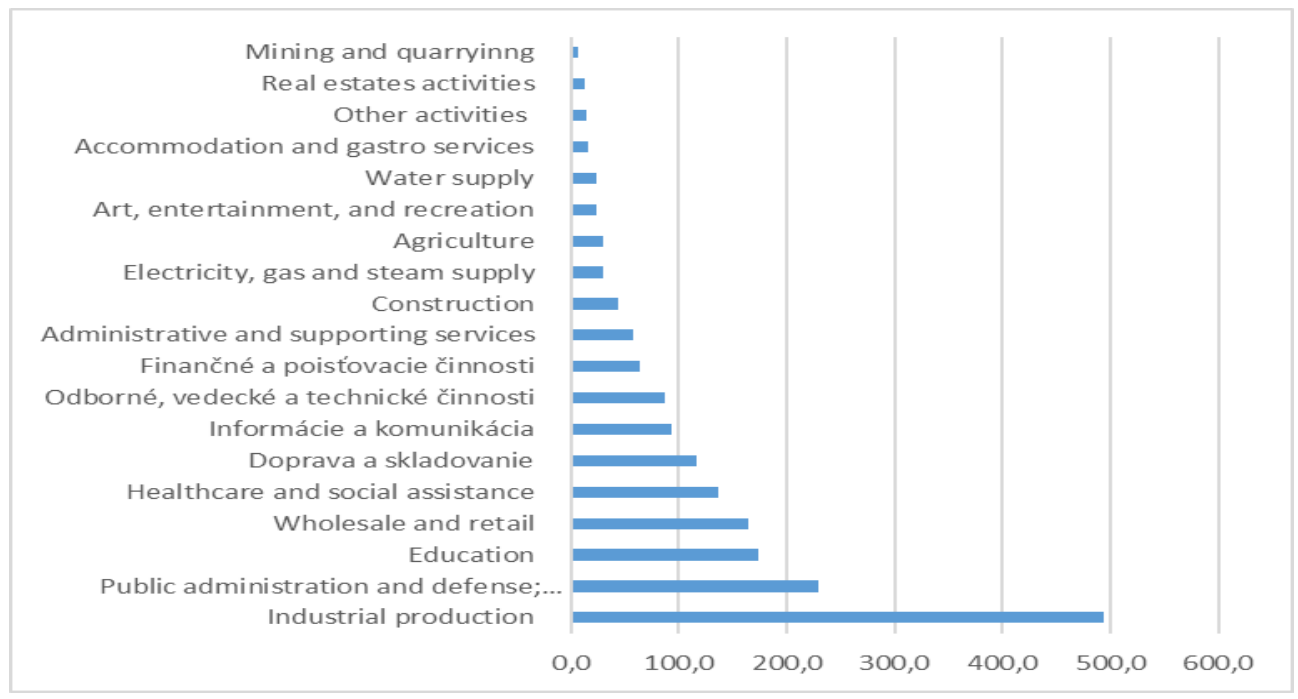

Graph 1 Volume of wages paid in individual branches in 2019 in mil. $€$

Source: own processing according to the Statistical Office of the Slovak Republic

The second parameter that has already been mentioned, influencing the occurrence of unused labor costs, is production decline. However, not all economic sectors were negatively affected by the crisis. The endangered companies can be divided into primary endangered and secondary endangered. In primarily endangered companies, there is a decline in production due to the closure of facilities by government decision, to ensure the protection of public health. These companies had to cease their activities completely, which meant that no revenues were achieved. In secondary endangered companies, they recorded a decline in revenues due to declining customer demand resulting from their new needs at the time of the coronavirus pandemic. Some companies might also have seen an increase in production volume due to increased customer demand, whether due to the loss of substitute products or purchasing of stocks. The biggest threat of unused labor costs is naturally in companies with the most significant decline in production.

Table 1. Non - productive labor costs in the event of a decline in production

\begin{tabular}{|c|r|r|}
\hline & \multicolumn{2}{|c|}{ Non - productive labor costs in \% of annual wages } \\
\hline $\begin{array}{c}\text { Production } \\
\text { decline by }\end{array}$ & $\begin{array}{c}\text { Duration of the decline } \\
\text { one month }\end{array}$ & $\begin{array}{c}\text { Duration of the decline } \\
\text { two months }\end{array}$ \\
\hline $10 \%$ & $0,8 \%$ & $1,7 \%$ \\
\hline $20 \%$ & $1,7 \%$ & $3,3 \%$ \\
\hline $30 \%$ & $2,5 \%$ & $5,0 \%$ \\
\hline $40 \%$ & $3,3 \%$ & $6,7 \%$ \\
\hline $50 \%$ & $4,2 \%$ & $8,3 \%$ \\
\hline $60 \%$ & $5,0 \%$ & $10,0 \%$ \\
\hline $70 \%$ & $5,8 \%$ & $11,7 \%$ \\
\hline $80 \%$ & $6,7 \%$ & $13,3 \%$ \\
\hline $90 \%$ & $7,5 \%$ & $15,0 \%$ \\
\hline $100 \%$ & $8,3 \%$ & $16,7 \%$ \\
\hline
\end{tabular}

Source: own processing 
According to an estimate of a 30\% slowdown in the economy over two months, the volume of non-productive labor costs can be expected to amount to $5 \%$ of annual wages. The highest value would achieve the costs in the industry sector. According to average wages in 2019, it would be more than 24.7 mil. $€$ (after taking into account levies of $€ 33.4$ million). Non-productive labor costs would represent up to $12.5 \%$ of annual wages in enterprises in which there has been a complete closure of operations or a production outage for 1.5 months. According to average wages in 2019, it would be, for example, in the arts, entertainment, and recreation sector, almost 3 mil. $€$ (after taking into account levies 4 mil. $€)$ and in the accommodation sector more than 1 mil. $€$ (with levies of almost $€ 1.4$ million)

\section{Conclusion}

The costs of human capital are an important component of the company's costs. In case of a significant decline in production, there is a non-productive component created, especially in the part of labor costs, which is a loss for the company. In terms of unused labor costs, the most vulnerable sector is the industry. In this sector, a high production outage can be estimated, especially due to the production outage and also the high volume of labor costs. Both of these factors are cumulative, especially in the automotive industry. Businesses that have been closed by government decision, and that have not achieved any revenues for a certain period are also at risk. Compensation provided by the state as compensation for employees' wages can be assessed positively in this situation. This measure will reduce the loss caused by unproductive labor costs of companies and will also improve the cash flow balance.

In terms of human capital costs, not only losses from unproductive labor costs can be perceived negatively, but also costs associated with possible redundancies. This factor would play a greater role in companies with higher wages and higher numbers of employees. Last but not least, a higher number of employees at risk of losing their jobs or a reduction in their income would also have an impact on the macroeconomic parameters of this situation, such as the unemployment rate and purchasing power.

\section{Note}

This contribution is a partial output of the VEGA project no. 1/0569/18 "Stabilization on Human Capital in Slovak Enterprises as an Immanent Determinant of their Success, Competitiveness and Sustainable Development " in the range of $100 \%$.

\section{References}

1. OECD, Centre for Educational Research and Innovation (CERI) Paris, 113 (1998).

2. L. Onnis, Human resource management policy choices, management practices and health workforce sustainability: remote Australian perspectives, Asia Pacific Journal of Human Resources 57, 3 - 23, (2019)

3. M. Amstrong, Ǩizení lidských zdroju: nejnovějši trendy a postupy. 10 vydanie. Praha: GRADA PUBLISHING, 2007, 789 s. (2007)

4. Y. Li, M. Wang, D. D. van Jaarsveld, G. K. Lee, D. G. Ma, From Employeeexperienced High-involvement Work System to Innovation: An Emergence-based Human Resource Management Framework. Academy of Management Journal 61, No 5 (2018) 
5. S. Kozhakhmet, S. Jayasingam, N. Majeed, S. Jamshed, When investment in employee development promotes knowledge sharing behavior in an uncertain post-Soviet context. Personnel Review 49 (2020)

6. S. Kakkar, S. Dash, N. Vohra, S. Saha, Engaging employees through effective performance management: an empirical examination,, Benchmarking: An International Journal 27, (2020)

7. D. Rybárová, Selekt problem of human capital management, In : G Dubcova a kol. Stabilization on Human Capital in Slovak Enterprises as an Immanent Determinant of their Success, Competitiveness and Sustainable Development Masaryk University, Brno, 113 - 118, (2019)

8. A.Tumasjan, F. Kunze, H. Bruch, I. M. Welpe, Linking employer branding orientation and firm performance: Testing a dual mediation route of recruitment efficiency and positive affective climate, Human Resource Management 59, 83-99 (2020)

9. S. T. Tseng, P. E. Levy, A multilevel leadership process framework of performance management. Human Resource Management Review 29, 100668 (2019)

10. D. Johnson, Ch. J. Lake, Contingent worker monetary influence, work attitudes and behavior, Personnel Review 48, (2019)

11. J. C. Gawke, M. J. Gorgievski, A. B. Bakker, Personal costs and benefits of employee intrapreneurship: Disentangling the employee intrapreneurship, well-being, and job performance relationship. Journal of Occupational Health Psychology 23 (4), 508$519,(2018)$

12. D. C. Jones, P. Kalmi, T. Kato, M. Mäkinen, The differing effects of individual and group incentive pay on worker separation: evidence using Finnish panel data. The International Journal of Human Resource Management 30, (2019)

13. C. S. Rigby, R. M. Ryan, Theory in Human Resource Development: New Directions and Practical Considerations, Human Resource Development International 20, (2018)

14. Ch. Juhn, K. McCue, H. Monti, B. Pierce, Firm Performance and the Volatility of Worker Earnings. Jurnal of Labor Economics 36, (2018)

15. R. Pečíková, Zamestnanci a priemerné mesačné mzdy v SR v roku 2019. Ústredie Štatistický úrad SR (2020) Retrieved from https://slovak.statistics.sk/

16. Urad verejného zdravotníctva SR, Opatrenie Úradu verejného zdravotníctva Slovenskej republiky pri ohrození verejného zdravia Č́́slo: OLP12595/2020 Bratislava 15.03.2020 Retrieved from http://www.uvzsr.sk/docs/info/covid19/Opatrenie_UVZ_SR_o_zakaze_a_obmedzeni_ prevadzok_15032020.pdf

17. Úrad verejného zdravotníctva SR, Opatrenie Úradu verejného zdravotníctva Slovenskej republiky pri ohrození verejného zdravia Č́́slo: OLP/3795/2020 Bratislava 05.05.2020 Retrieved from http://www.uvzsr.sk/docs/info/covid19/Opatrenie_UVZ_SR_o_zakaze_a_obmedzeni_ prevadzok_15032020.pdf

18. E. Frantová, B. Toma, Premiér neprekvapil. Obchody zostávajú zatvorené, Pravda 14.4.2020 Retrieved from https://ekonomika.pravda.sk/ 